SAKAI SAMBAYAN — Jurnal Pengabdian kepada Masyarakat

\title{
PEMANFAATAN LIMBAH PERTANIAN SEBAGAI PEMENUHAN KEBUTUHAN PAKAN TERNAK RUMINANSIA DI DESA RUKTI ENDAH KECAMATAN SEPUTIH RAMAN KABUPATEN LAMPUNG TENGAH
}

\author{
Eko Budiyanto $^{1 *}$, Yusuf Amran ${ }^{1}$ \\ ${ }^{1}$ Jurusan Teknik Mesin Universitas Muhammadiyah Metro \\ Jl. Ki Hajar Dewantara No. 116 Metro 34111, Lampung, Indonesia \\ Penulis Korespodensi : eko_budiyanto99@yahoo.com
}

\begin{abstract}
Abstrak
Permasalahan warga yang memiliki ternak ruminansia adalah pada musim kemarau mengalami kesulitan dalam bidang pengadaan pakan hijauan berupa rumput untuk ternak mereka. Hal itu disebabkan stok pakan sangat terbatas pada musim kemarau, namun berbeda kondisi jika pada musim penghujan, saat musim panen padi, dan panen jagung. Jerami padi dan pelepah jagung merupakan limbah pertanian warga kecamatan Seputih Raman yang oleh masyarakat sekitar hanya dibakar dalam mempersiapkan lahan untuk penanaman berikutnya. Beberapa solusi yang ditawarkan adalah teknologi pakan silase berbahan baku jerami padi dan pelepah jagung berfungsi menjembatani stok pakan pada musim hujan dan musim kemarau. Dalam pembuatan silase, bahan pakan terlebih dahulu dicacah sekitar $1-5 \mathrm{~cm}$. Solusi penawaran berikutnya adalah tim pengabdi membantu membuatkan mesin pencacah untuk memudahkan mitra dalam mencacah pakan ternak sebelum dibuat silase. Dalam hal ini tim pengabdi juga memberikan penyuluhan pengoperasian dan perawatan mesin pencacah pakan ternak serta pelatihan cara pembuatan silase pakan ternak. Hasil dari kegiatan ini adalah warga mitra dapat mengoperasikan dan merawat mesin pencacah pakan ternak untuk memanfaatkan potensi lokal sebagai solusi permasalahan pakan ternak sehingga kebutuhan pakan ternak di musim kemarau menjadi terbantu.
\end{abstract}

Kata kunci: limbah pertanian, pakan ternak, silase

\section{Pendahuluan}

Sistem pemeliharaan ternak kambing di Indonesia sekitar $80 \%$ masih diusahakan oleh petani kecil yang berkembang di beberapa wilayah pedesaan (Winarso, 2010). Usaha pemeliharaan ternak kambing dalam skala kecil dapat membantu perekonomian petani di pedesaan dengan memanfaatkan sumberdaya alam yang tersedia di sekitarnya. Kambing mempunyai beberapa keunggulan diantaranya membutuhkan modal usaha yang relatif kecil, mudah memeliharanya, mudah menjualnya dan banyak digunakan sebagai bahan-bahan kuliner seperti sate, gulai, dam tongseng. Selain itu, berbagai acara keperluan keluarga seperti tasyakuran maupun acara lainnya yang berhubungan dengan ritual keagamaan seperti hewan qurban pada hari raya keagamaan dan aqiqah juga menggunakan hewan kambing (Rusdiana \& Sutedi, 2014).

Selain ternak kambing, sapi merupakan salah satu dari lima komoditas yang menjadi konsentrasi utama pembangunan pertanian selain padi, jagung, kedelai, dan gula tebu. Sehingga Kementerian Pertanian masih mencanangkan upaya swasembada daging sapi dan kerbau. Oleh karena itu, upaya untuk mendukung pembangunan peternakan sapi dari aspek pakan perlu dilakukan. Mayoritas masyarakat pedesaan di Indonesia berprofesi sebagai petani, dan mempunyai banyak limbah pertanian. Pemanfaatan limbah pertanian, seperti jerami padi, jerami kacang tanah, rumput, dan dedaunan sebagai pakan basah merupakan upaya yang dapat dilakukan untuk meningkatkan efisiensi usaha, yaitu dengan menekan biaya pakan (Suwignyo dkk., 2016).

Hasil penelusuran tim penulis, di desa Rukti Endah kecamatan Seputih Raman kabupaten Lampung Tengah mayoritas warganya adalah petani padi dan jagung. Namun sebagai usaha sampingan untuk pemenuhan kebutuhan, selain bertani mereka juga memelihara ternak berupa kambing dan sapi. Namun keluhan warga dalam beternak adalah masalah pakan ternak yang tidak menentu. Di musim penghujan pemenuhan 
kebutuhan pakan ternak memang tercukupi, namun tidak sama halnya ketika musim kemarau.

Sebenarnya potensi bahan pakan untuk ternak di desa Rukti Endah sangat melimpah. Situasi ini terjadi ketika musim panen padi dan jagung. Limbah sisa pertanian seperti jerami padi dan pelepah pohon jagung dibakar untuk persiapan lahan tanam selanjutnya. Kurangnya pemanfaatan jerami padi sebagai salah satu bahan pakan ternak yaitu kandungan serat kasar tinggi dan protein serta kecernaan yang rendah. Penggunaan jerami secara langsung sebagai pakan tunggal tidak dapat memenuhi pasokan nutrisi yang dibutuhkan ternak.Untuk dapat memanfaatkan limbah yang berlimpah maka perlu dilakukan suatu upaya peningkatan daya guna dari limbah tersebut melalui suatu teknologi pakan yang tepat guna. Salah satu teknologi pakan tepat guna yang dilakukan dalam pengolahan bahan pakan ternak adalah bioteknologi melalui fermentasi (Afandi, 2014). Tentu ini merupakan potensi yang baik untuk dapat memenuhi kebutuhan pakan ternak apabila limbah jerami padi dan pelepah jagung tersebut diolah melalui proses fermentasi menjadi silase. Sehingga petani tidak akan mengalami kesulitan pakan ternak saat musim kemarau. Namun pemasalahannya adalah masyarakat tidak memahami bagaimana cara memanfaatkan potensi tersebut sebagai pemenuhan kebutuhan pakan ternak mereka.
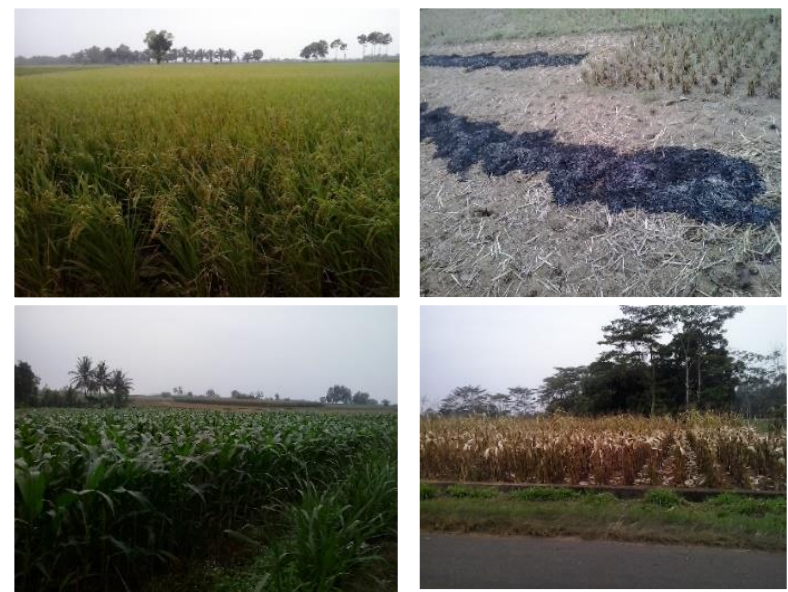

Gambar 1. Limbah pertanian yang tak termanfaatkan (jerami padi dan pelepah jagung). Sumber; dokumentasi pribadi

Proses pembuatan pakan ternak fermentasi dilakukan dengan cara mencacah bahan baku yang berupa jerami atau rumput menjadi potongan kecilkecil sekitar $1-5 \mathrm{~cm}$, selanjutnya bahan baku ini dihamparkan dan semprot dengan fermentator biosilase, setelah disemprot bahan dimasukkan kedalam drum untuk difermentasi sekitar satu minggu. Semakin kecil ukuran bahan baku maka permukaan yang terkontak dengan fermentor akan semakin baik, dan ini akan menghasilkan mutu pakan ternak yang baik (Susilo, Widodo, \& Ubaidillah, 2012).

Untuk beberapa permasalahan para petani ternak tersebut, maka perlu adanya perbaikan produksi dan kualitas ternak dengan jalan memanfaatkan limbah pertanian berupa jerami padi maupun pelepah jagung (tebon) sebagai pemenuhan kebutuhan pakan ternak ruminansia di Desa Rukti Endah Kecamatan Seputih Raman Kabupaten Lampung Tengah.

\section{Metode}

\section{A. Waktu, Lokasi dan Peserta Kegiatan}

Kegiatan pengabdian dilaksanakan selama bulan April sampai dengan Juli 2018. Kegiatan dilakukan di rumah salah satu mitra pengabdian di Desa Rukti Endah 5, Kecamatan Seputih Raman, Kabupaten Lampung Tengah. Peserta dari kegiatan ini adalah Kelompok ternak ruminansia setempat yakni kelompok ternak Moga Maju beranggotakan 5 orang dan kelompok Ternak Berkah Ternak yang juga beranggotakan 5 orang.

\section{B. Bahan dan Peralatan}

Bahan utama yang digunakan dalam kegiatan pengabdian ini adalah limbah pertanian warga berupa jerami padi dan pohon jagung (tebon). Bahan tambahan berupa EM4, dedak halus, dan molasses (tetes tebu). Peralatan yang digunakan adalah mesin pencacah paka ternak, terpal, plastik besar, dan karet tali.

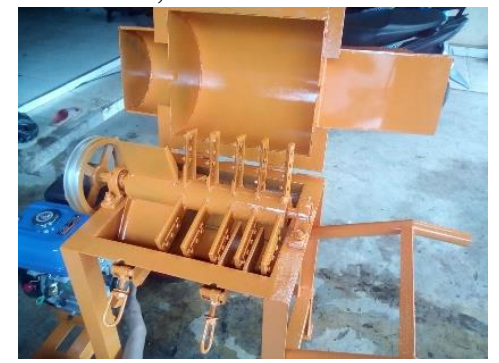

Gambar 2. Mesin Pencacah Pakan ternak

\section{Metode Pelaksanaan Kegiatan}

Pada kegiatan awal pelaksanaan, ketua pelaksana melakukan sosialisasi dan koordinasi dengan mitra warga RT 5 dusun 5 Rukti Endah kecamatan Seputih Raman kabupaten Lampung Tengah, tentang kegiatan PKM. Sosialisasi program kerja dan langkah-langkah realisasi 
program kerja merupakan fokus utama dalam sosialisasi dan koordinasi. Kegiatan yang dilakukan adalah musyawarah kelompok, identifikasi permasalahan tentang pemenuhan kebutuhan pakan ternak, pembuatan menin pencacah pakan ternak, pelatihan pengoperasian serta perawatan mesin pencacah pakan ternak, serta pelatihan dan pembuatan silase pakan ternak.

Adapun uraian tahapan yang dilaksanakan untuk menyelesaikan persoalan mitra warga dusun 5 desa Rukti Endah kecamatan Seputih Raman kabupaten Lampung Tengah ialah:

1. Musyawarah kelompok

Musyawarah kelompok adalah tahap awal untuk memulai kegiatan. Beberapa warga dusun 5 desa Rukti Endah kecamatan Seputih Raman kabupaten Lampung Tengah adalah sebagai petani yang juga sebagai peternak kambing dan sapi. Kelompok Moga Maju adalah kelompok ternak yang terbentuk oleh warga RT 3 dusun 5 desa Rukti Endah kecamatan Seputih Raman kabupaten Lampung Tengah. Dan kelompok Berkah Ternak adalah kelompok yang terbentuk oleh warga RT 5 dusun 5 desa Rukti Endah kecamatan Seputih Raman kabupaten Lampung Tengah. Kelompok Moga Maju dan kelompok Berkah Ternak ini sebagai Mitra 1 dan Mitra 2. Mitra 1 memiliki ternak kambing dan mitra 2 memiliki ternak sapi. Dari musyawarah kelompok, tersusun jadwal kegiatan untuk penyuluhan, pembuatan \& pelatihan mengoperasikan mesin pencacah pakan ternak, serta pelatihan dan pembuatan silase pakan ternak.

2. Identifikasi Permasalahan

Tahapan ini merupakan tahapan lanjutan setelah terbentuknya kelompok peternak kambing. Kegiatan ini dilakukan dengan cara mengidentifikasi berbagai permasalah yang dihadapi kelompok peternak kambing, antara lain permasalahan pemenuhan pakan ternak saat musim kemarau.

3. Pebuatan mesin pencacah pakan ternak

Tahapan yang keempat adalah pembuatan mesin pencacah pakan ternak. Pembuatan mesin pencacah pakan ternak ini bertujuan untuk memudahkan warga/mitra dalam persiapan awal pembuatan silase dari jerami padi dan pelepah jagung. Tim pengabdi merancang dan membuatkan mesin pencacah pakan ternak. Luaran dari tahapan ini adalah produk mesin pencacah pakan ternak yang sesuai kebutuhan sebagai solusi mengatasi permasalahan pakan ternak.

4. Pelatihan pengoperasian dan perawatan mesin pencacah

Setelah pembuatan mesin pencacah pakan ternak selesai, maka tahapan selanjutnya adalah melakukan pelatihan pengoperasian dan perawatan mesin pencacah dengan praktek langsung cara pengoperasian alat. Ini adalah tahapan yang kelima. Karena mengoperasikan mesin memerlukan keselamatan kerja, maka pelatihan pengoperasian dan perawatan mesin pencacah pakan ternak ini penting untuk warga mitra. Tujuannya agar mitra dapat mengoperasikan mesin pencacah pakan ternak untuk memanfaatkan potensi lokal sebagai solusi permasalahan pakan ternak.

5. Pelatihan dan pembuatan silase pakan ternak.

Pelatihan dan pembuatan silase pakan ternak ini adalah tahapan yang terakhir dari kegiatan pengabdian ini. Diawali dengan persiapan bahan utama pakan berupa jerami padi dan pelepah jagung, dilanjutkan dengan persiapan alat dan bahan campuran yang digunakan dalam pembuatan silase pakan ternak. Pada tahapan ini warga Mitra 1 dan Mitra 2 bersama dengan tim pengabdi terjun langsung ke lokasi untuk melaksanakan pembuatan silase pakan ternak. Tujuan dari tahapan pembuatan silase ini adalah mitra mengetahui tentang fermentasi pakan ternak dan dapat membuat sendiri fermentasi pakan untuk pemenuhan kebutuhan pakan ternak.

\section{Hasil}

Pelaksanaan kegiatan pengabdian kepada masyarakat mendapatkan hasil yang telah dicapai yakni :

1. Melalui kegiatan ini, warga mitra memahami permasalahan pakan dan cara penanggulangannya dengan memanfaatkan potensi lokal yang melimpah,

2. Warga mitra memiliki pengetahuan tentang mesin pencacah pakan ternak dan dapat mengoperasikan, merawat, serta menerapkan K3 dalam pengoperasian mesin pencacah pakan ternak,

3. Warga mitra dapat membuat fermentasi pakan ternak (silase). 

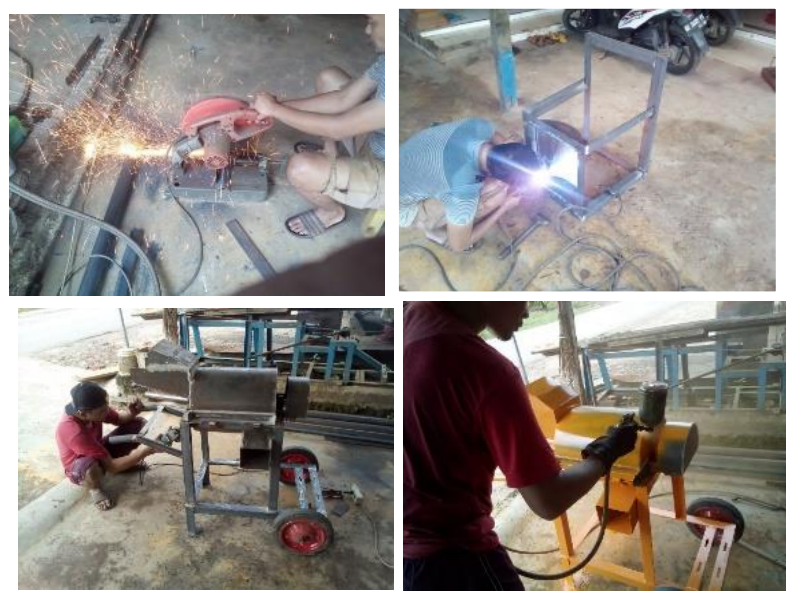

Gambar 3. Pembuatan Mesin Pencacah Pakan Ternak
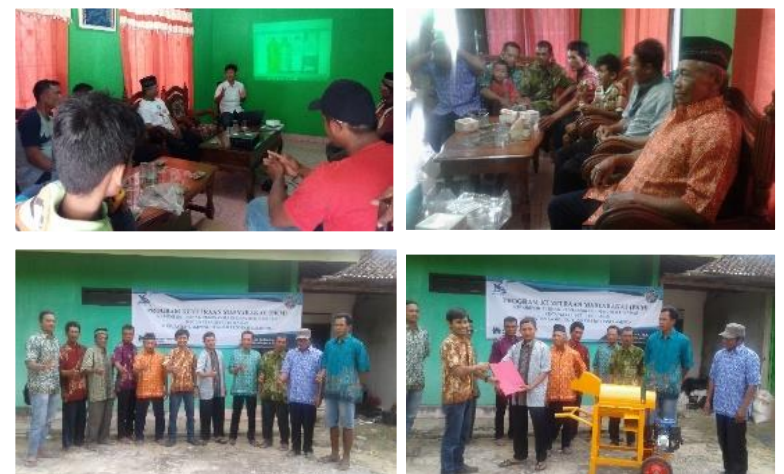

Gambar 4. Kegiatan Sosialisasi dan Serah Terima Alat
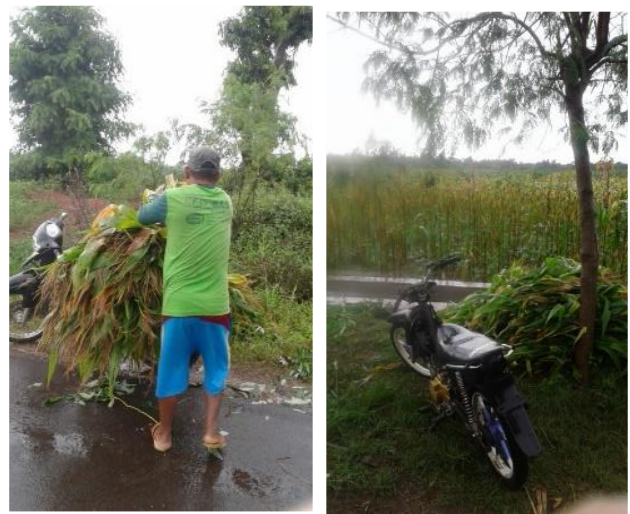

Gambar 5. Pengumpulan Bahan Baku Pembuatan Silase
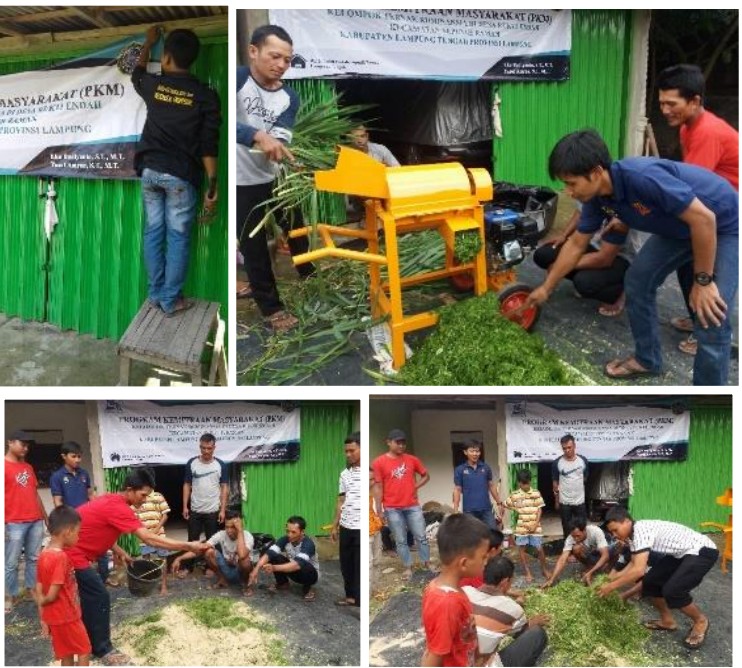

Gambar 6. Pelatihan Pembuatan Silase

\section{Kesimpulan}

Adanya kegiatan pengabdian kepada masyarakat Program Kemitraan Masyarakat dengan judul: PKM Kelompok Ternak Ruminansia di Desa Rukti Endah Kecamatan Seputih Raman Kabupaten Lampung Tengah Provinsi Lampung, masalah yang dihadapai mitra dapat terselesaikan. Dalam kegiatan Ibm ini yang dihasilkan adalah:

1. Warga mitra memahami permasalahan pakan dan cara penanggulangannya dengan memanfaatkan potensi lokal yang melimpah,

2. Warga mitra memiliki pengetahuan tentang mesin pencacah pakan ternak dan dapat mengoperasikan mesin pencacah pakan ternak,

Warga mitra dapat membuat fermentasi pakan ternak (silase).

\section{Ucapan Terima Kasih}

Terima kasih disampaikan kepada:

1. KEMENRISTEK-DIKTI yang telah mendanai kegiatan pengabdian ini,

2. LPPM UM Metro,

Rekan-rekan FT UM Metro.

\section{Daftar Pustaka}

Afandi. (2014). NILAI NUTRISI SILASE PAKAN KOMPLIT BERBAHAN DASAR JERAMI PADI DAN BIOMASSA MURBEI. Makassar: UNIVERSITAS HASANUDDIN.

Naifa, R., R, O., B , N. T., \& Detha, A. A. (2015, Juni 4). Kualitas Nutrisi Silase Rumput Gajah (Pennisetum purpureum) yang Diberi Dedak Padi dan Jagung Giling dengan Level Berbeda. 
Journal of Animal Science Vol. 1 No. 1, hal. 68.

Rusdiana, S., \& Sutedi, E. (2014, September). ANALISIS PRODUKSI RUMPUT Brachiaria DALAM PENGEMBANGAN USAHA TERNAK KAMBING. Jurnal Peternakan Vol 11 No 2, hal. 69 - 77.

Subekti, E. (2009). KETAHANAN PAKAN TERNAK INDONESIA. MEDIAGRO VOL 5. NO 2, hal. $63-71$.

Susilo, D. D., Widodo, P. J., \& Ubaidillah. (2012, September). MEKANISASI PROSES
PENCACAHAN BAHAN PAKAN TERNAK DALAM PEMBUATAN PAKAN TERNAK FERMENTASI. MEKANIKA VOL. 11 NO. 1 , hal. 31-36.

Winarso, B. (2010). Prospek dan kendala pengembangan agribisnis ternak kambing dan domba di Indonesia. Peningakatan Daya Saing Agribisnis Berorientasi Kesejahteraan Petani, (hal. 246-264). Pusat Analisis Soasial Ekonomi dan Kebijakan Pertanian Kementrian Pertanian. 